\title{
Specimen size effect on superplastic flow behavior of electrodeposited nanocrystalline nickel
}

\author{
M. J. N. V. Prasad \\ mjnvprasad@iitb.ac.in \\ Department of Metallurgical Engineering and Materials Science, Indian Institute of Technology Bombay, Powai, \\ Mumbai-400076, India

\begin{abstract}
Nanocrystalline nickel foils with a grain size of $\sim 12 \mathrm{~nm}$ are produced by pulsed current electrodeposition using a modified Watts electrolytic bath. Saccharin, a sulfur-based organic compound, used as a grain refiner and stress reliever to produce free-standing Ni foils. Nano-Ni tensile specimens displayed superplastic elongations $(>400 \%)$ at high strain rate of $3 \times 10^{-1} \mathrm{~s}^{-1}$ and relatively low temperature of $777 \mathrm{~K}$. Tensile specimens with different gauge lengths and thicknesses exhibited significant specimen size effect on maximum stress, elongation to failure and flow behavior under superplastic conditions. An increased total elongation to failure with increasing the specimen thickness and decreasing the gauge length was observed in the electrodeposited $\mathrm{Ni}$ foils. The stress-strain behavior of Ni changed from strain hardening to strain softening with increasing the specimen thickness. Strain rate jump tests indicated a very high strain rate sensitivity index values $(m \sim 0.5-0.8)$ for nano-Ni specimens at $777 \mathrm{~K}$ with a slight increased value of $m$ with increasing the specimen thickness. The as-deposited nano-Ni samples showed substantial grain growth during heating and deformation as well at the testing temperature of $777 \mathrm{~K}$. Microstructural investigation revealed that the total number of grains across specimen thickness and the formation of oxide layer during high temperature deformation can influence the superplasticity characteristics of nanocrystalline Ni.
\end{abstract}

Keywords: superplasticity, electrodeposition, nanocrystalline, nickel, size effect

\section{Влияние размера образца на сверхпластическое поведение электроосажденного нанокристаллического никеля}

\begin{abstract}
Путем электроосаждения пульсирующим током в модифицированной электролитической ванне Уоттса получены фольги нанокристаллического никеля с размером зерен около 12 нм. Для получения отделенных фольг никеля, измельчения зерен и релаксации напряжений было использовано органическое вещество на основе серы - сахарин. Образцы нано-никеля для растяжения продемонстрировали сверхпластические удлинения (выше 400\%) при высокой скорости деформации $3 \times 10^{-1} \mathrm{c}^{-1}$ и относительно низкой температуре 777 К. Образцы для растяжения с различными длинами рабочих частей и толщинами показали значительное влияние размера образцов на максимальное напряжение, удлинение до разрушения и характер течения в условиях сверхпластичности. На электроосажденных образцах $\mathrm{Ni}$ наблюдалось увеличение полного удлинения до разрушения с увеличением толщины образцов и уменьшением рабочей длины. Характер кривой напряжение-деформация Ni изменился от упрочнения к разупрочнению с увеличением толщины образцов. Испытания со скачком скорости деформации показали очень высокий показатель скоростной чувствительности $(m \sim 0.5-0.8)$ для образцов нано-Ni при 777 К с небольшим повышением значения $m$ с увеличением толщины образцов. Образцы электроосажденного нано-Ni показали существенный рост зерен при нагреве и деформации, а также при температуре испытаний of 777 К. Микроструктурные исследования показали, что на характеристики сверхпластичности нанокристаллического Ni могут влиять полное число зерен по толщине образца и образование оксидного слоя при высокотемпературной деформации.
\end{abstract}

Ключевые слова: сверхпластичность, электроосаждение, нанокристаллический, никель, размерный эффект

\section{Introduction}

Nanocrystalline (grain size, $d<100 \mathrm{~nm}$ ) and ultrafine-grained (UFG, $d<1 \mu \mathrm{m}$ ) materials have been the areas of scientific in- terest for the past three decades because of their exceptional and unusual physical, chemical and mechanical properties [1-5]. Several methods have been developed to synthesize nanocrystalline and UFG materials; however, producing 
fully dense nanocrystalline materials in bulk form is quite challenging. Severe plastic deformation (SPD) methods with top-down approach have been very successful in producing bulk materials with grain size down to $50 \mathrm{~nm}$. Electrodeposition technique, one of the bottom-up approaches, can also be used to produce fully dense bulk nanocrystalline and UFG materials by manipulating chemical bath and electrical energy supply.

The field of superplasticity has gained enough scientific interest and technological importance as well. Typical superplastic strain rates exhibited by conventional superplastic metallic materials $(d \sim 1-10 \mu \mathrm{m})$ are usually in the range of $\sim 10^{-4}-10^{-3} \mathrm{~s}^{-1}$ at temperatures greater than $0.5 T_{m}$ (where $T_{m}$ is the absolute melting temperature), but these strain rates are quite low for any forming applications [6]. As the strain rate of deformation is inversely proportional to the grain size, the reduction of grain size below $1 \mu \mathrm{m}$ can lead to an improved superplastic strain rates. In this context, nanocrystalline and UFG materials are believed to be potential superplastic materials to exhibit high strain rate (typically, $\left.>10^{-2} \mathrm{~s}^{-1}\right)$ superplasticity $[7,8]$. Several studies confirmed that electrodeposited nanocrystalline $\mathrm{Ni}, \mathrm{Ni}$ alloys and $\mathrm{Ni}$ based metal matrix composites are class of superplastic materials which can exhibit extraordinary superplastic elongations, $>400 \%$ over a range of conventional to high strain rates [9-13].

Specimen size effect is one of the external size effects which influence the mechanical properties of a polycrystalline material. The specimen for uniaxial tensile testing contains three basic dimensions such as length, width and thickness of a gauge section, with the conventional gauge dimensions in centimeters. Tensile testing of nanocrystalline and UFG materials involves non-conventional specimen dimensions because of the limitation of processing routes in obtaining bulk materials. Several studies have examined the specimen size effect to validate the use of small specimens. There were several reports on specimen size effect on strength and ductility at room temperature [14-18]. There are a limited data on specimen dimensions effect on superplastic behavior [19-21]. Nevertheless, the research on size effect of mechanical properties is still going on. Since nanocrystalline and UFG materials are potential materials for low temperature/high strain rate superplasticity, it is necessary to study the specimen size effects on tensile properties of nano- and UFG materials under superplastic conditions. It is important to note that $\mathrm{McFadden}$ et al. [9] reported the elongation to failure of $\sim 890 \%$ in electrodeposited nano-Ni tensile specimens having small gauge lengths of $1 \mathrm{~mm}$. Since most studies indicated an increase in ductility with decreasing gauge length, it is not clear whether the large ductility in nano- $\mathrm{Ni}$ is related to the smaller gauge length. Moreover, unlike the conventional superplastic materials the electrodeposited materials are foils with thickness less than $0.5 \mathrm{~mm}$. Therefore, in this present investigation, nanocrystalline $\mathrm{Ni}$ (nano-Ni) foils of different thicknesses produced by pulsed electrodeposition are tested at elevated temperature to evaluate the effect of specimen size in terms of thickness and gauge length on superplastic deformation behavior. Detailed microstructural investigation was conducted to assess the specimen size effect on superplastic strength and ductility of nano-Ni.

\section{Experimental Procedure}

Free-standing nanocrystalline $\mathrm{Ni}\left(d_{0} \sim 12 \mathrm{~nm}\right)$ foils were produced by pulsed electrodeposition using a modified Watts bath as an electrolyte with saccharin as a grain refiner and a stress reliever. Pulsed current electrodeposition route facilitates the use of high current densities for easy nanocrystallization during short on-time period followed by zero current off-time period cycle for replenishment of electrolyte near substrate. Foils with a varying thickness ranging from 25 to $150 \mu \mathrm{m}$ were obtained by varying the time of deposition from 1 to $5 \mathrm{~h}$. Additional details of chemical bath composition and deposition parameters used can be found elsewhere [11]. Nanocrystalline nickel foils containing 1000 ppm sulfur (obtained by addition of S-based organic compound, saccharin) are used for the present investigation.

Electrical discharge machined and subsequently electropolished nanocrystalline $\mathrm{Ni}$ specimens with a gauge width of $2 \mathrm{~mm}$ but with different gauge lengths $(1-5 \mathrm{~mm})$ and thicknesses $(17-120 \mu \mathrm{m})$ were tested in tension at a temperature of $777 \mathrm{~K}$ and an initial strain rate of $3 \times 10^{-1} \mathrm{~s}^{-1}$. These testing conditions, where nanocrystalline $\mathrm{Ni}$ displayed exceptional superplastic characteristics, were chosen based on previous study [11]. Strain rate jump tests were performed at $777 \mathrm{~K}$ for determining the strain rate sensitivity index $(m)$. Additional details related to tensile specimen dimensions and tension test procedure used can be found in $[10,11]$. Scanning electron microscopy (SEM) was carried out for examining the microstructure of specimens before and after superplastic deformation.

\section{Results}

Tensile deformation data of electrodeposited nanocrystalline $\mathrm{Ni}$ foils are presented in two sub-sections, namely, specimen gauge length effect and specimen thickness effect for examining the size effect on superplasticity characteristics. Detailed microstructural investigation conducted on samples heated to test temperature and the specimens deformed under superplasticity conditions is included for assessing the reasons for the observed size effect.

\section{(a) Specimen gauge length effect}

Nanocrystalline Ni tensile specimens with four different gauge lengths $\left(L_{0}\right)$ of $5 \mathrm{~mm}, 2 \mathrm{~mm}, 1.5 \mathrm{~mm}$ and $1 \mathrm{~mm}$ were tested at $777 \mathrm{~K}$ and at an initial strain rate of $3 \times 10^{-1} \mathrm{~s}^{-1}$. The gauge width (b) and thickness $\left(\mathrm{t}_{0}\right)$ were $2 \mathrm{~mm}$ and $\sim 85 \mu \mathrm{m}$, respectively. Figure 1 shows the effect of gauge length on superplastic behavior of nano-Ni for the same initial strain rates and test temperature. The nominal elongation to failure and stress increased with decreasing the gauge length. There was significant change in flow behavior with gauge length. Specimens with smaller gauge lengths exhibited nearly steady state flow whereas the specimen with $5 \mathrm{~mm}$ gauge length displayed flow softening. The present study clearly shows that the superplastic behavior of nanocrystalline and UFG materials is affected by the tensile specimen size. 


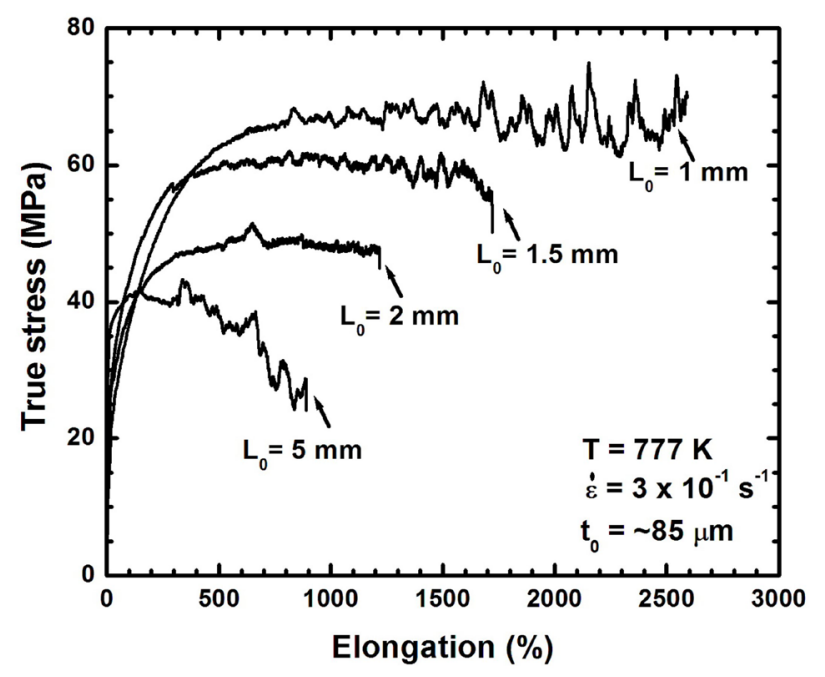

Fig. 1. A plot of nominal true stress-elongation showing the effect of specimen gauge length on superplastic deformation of nano-Ni tested at $777 \mathrm{~K}$ and $3 \times 10^{-1} \mathrm{~s}^{-1}$.

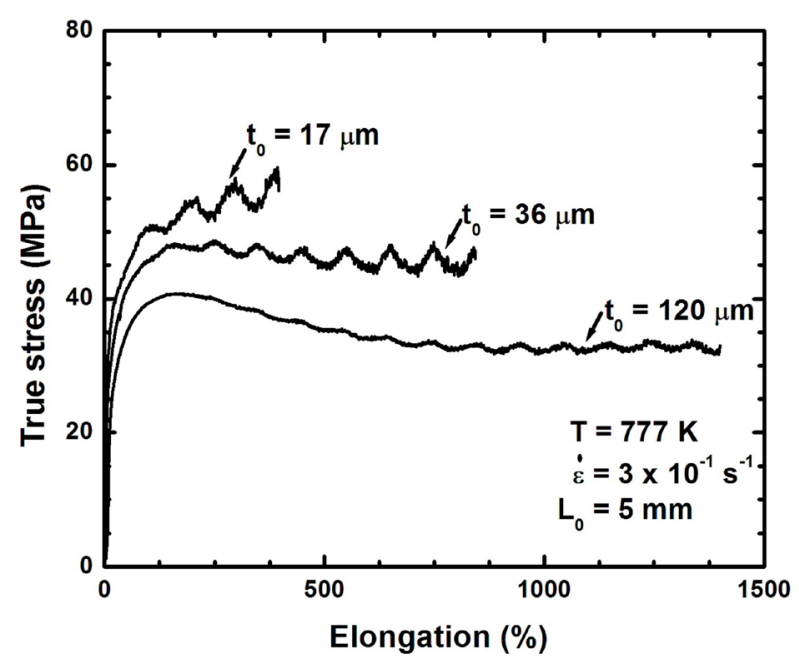

Fig. 2. True stress-elongation plot showing the effect of specimen thickness on superplasticity of nano-Ni.

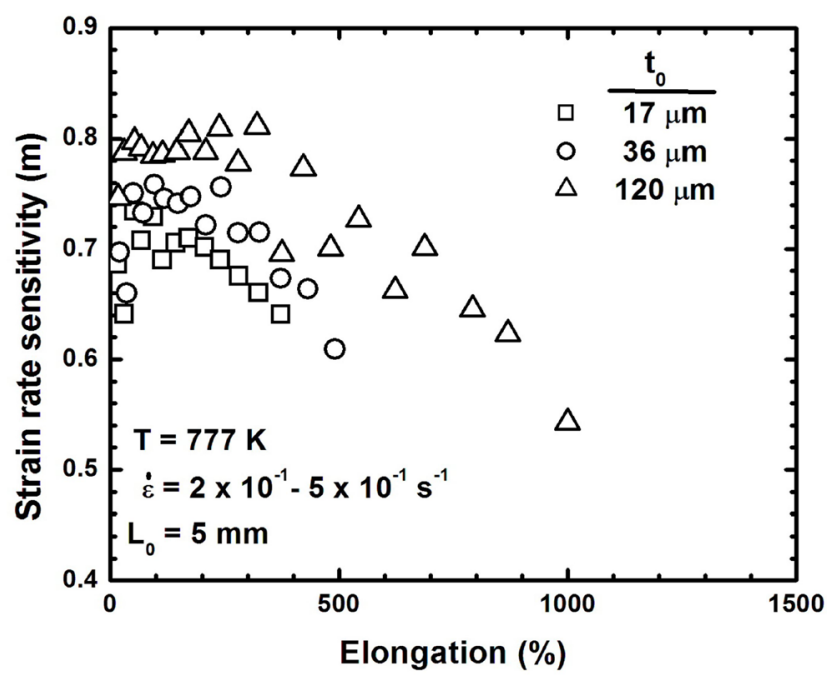

Fig. 3. Variation of strain rate sensitivity (m) with strain for nano-Ni specimens with different thicknesses.
Table 1. Mechanical properties and microstructural changes of nano-Ni specimens with three different thicknesses tested at $777 \mathrm{~K}$ and $3 \times 10^{-1} \mathrm{~s}^{-1}$

\begin{tabular}{|c|c|c|c|c|c|c|}
\hline \multirow[b]{2}{*}{$\begin{array}{c}\mathrm{t}_{0} \\
(\mu \mathrm{m})\end{array}$} & \multirow[b]{2}{*}{$\begin{array}{c}\sigma_{\max } \\
(\mathrm{MPa})\end{array}$} & \multirow[b]{2}{*}{$\begin{array}{l}\mathrm{e}_{\mathrm{f}} \\
(\%)\end{array}$} & \multirow[b]{2}{*}{$\begin{array}{c}t_{f} \\
(\mu \mathrm{m})\end{array}$} & \multirow{2}{*}{$\begin{array}{c}\text { Grain } \\
\text { aspect } \\
\text { ratio }\end{array}$} & \multicolumn{2}{|c|}{ Grain size after test } \\
\hline & & & & & $\begin{array}{c}\text { Grip } \\
\mathrm{d}_{\text {grip }}(\mathrm{nm})\end{array}$ & $\begin{array}{l}\text { Near tip } \\
\mathrm{d}_{\text {tip }}(\mathrm{nm})\end{array}$ \\
\hline 17 & 60 & 400 & 9 & 1.3 & $540 \pm 10$ & $680 \pm 30$ \\
\hline 36 & 50 & 840 & 13 & 1.4 & $560 \pm 20$ & $850 \pm 40$ \\
\hline 120 & 40 & 1400 & 24 & 1.5 & $530 \pm 20$ & $850 \pm 30$ \\
\hline
\end{tabular}

\section{(b) Specimen thickness effect}

Nanocrystalline Ni specimens with an initial gauge length $\left(L_{0}\right)$ of $5 \mathrm{~mm}$ and width $(b)$ of $2 \mathrm{~mm}$ but of three different thicknesses $\left(\mathrm{t}_{0}\right) \sim 17 \mu \mathrm{m}, 36 \mu \mathrm{m}$ and $120 \mu \mathrm{m}$ were tested at $777 \mathrm{~K}$ with an initial strain rate of $3 \times 10^{-1} \mathrm{~s}^{-1}$. Figure 2 shows the effect of specimen thickness on superplastic behavior of electrodeposited nano-Ni. Mechanical properties such as the maximum stress $\left(\sigma_{\max }\right)$ and elongation to failure $\left(e_{f}\right)$ for different specimen thicknesses are given in Table 1. The nominal elongation to failure decreased but the strength increased with decreasing the specimen thickness. There were serrations in flow curves, but the onset strain for the serrations increased with increasing the specimen thickness. The flow behavior changed from strain softening to strain hardening with decreasing the specimen thickness. The strain rate sensitivity $(m)$ of nano-Ni with different thicknesses was measured by strain rate jump test between $2 \times 10^{-1} \mathrm{~s}^{-1}$ and $5 \times 10^{-1} \mathrm{~s}^{-1}$ at $777 \mathrm{~K}$. Variation of $m$ with strain for different specimen thicknesses is shown in Fig. 3. It was noted that nano-Ni exhibited a very high $m$ values $(0.5-0.8)$ at testing conditions. And, the $m$ value decreased slightly with decreasing specimen thickness and increasing strain.

\section{(c) Microstructural investigation}

Figure 4 shows the secondary electron micrographs of nanocrystalline Ni sample heated to a test temperature of $777 \mathrm{~K}$ (Fig. 4a) and also the micrographs of the tensile specimens (near fracture tip) of three different thicknesses (Fig. 4b-c) deformed at $777 \mathrm{~K}$ and $3 \times 10^{-1} \mathrm{~s}^{-1}$. The grain size of nano-Ni sample heated to the test temperature of $777 \mathrm{~K}$ increased to $450 \pm 15 \mathrm{~nm}$ from the as-deposited grain size of $\sim 12 \mathrm{~nm}$. The nano-Ni samples heated to the test temperature contained significant volume fraction $(\sim 0.7 \%)$ of $\mathrm{Ni}_{3} \mathrm{~S}_{3}$ particles (encircled regions in Fig. 4a). There was substantial deformation-induced grain growth and cavitation in superplastically deformed nano-Ni specimens. The final thickness $\left(t_{f}\right)$ of the deformed specimen, the grain aspect ratio, and the grain size at grip and near fracture tip of nano-Ni for different specimen thicknesses are reported in Table 1. It appeared to be that except cavitation there were no remarkable changes with variation in the specimen thickness.

There was significant oxidation of nano- $\mathrm{Ni}$ as the tensile tests were conducted in air. Figure 5 shows fracture and surface morphology of the nano-Ni specimen deformed at 777 K. Fig. $5 \mathrm{a}$ is a typical fracture surface of the nano-Ni specimen deformed at superplastic temperatures and it reveals an inter- 

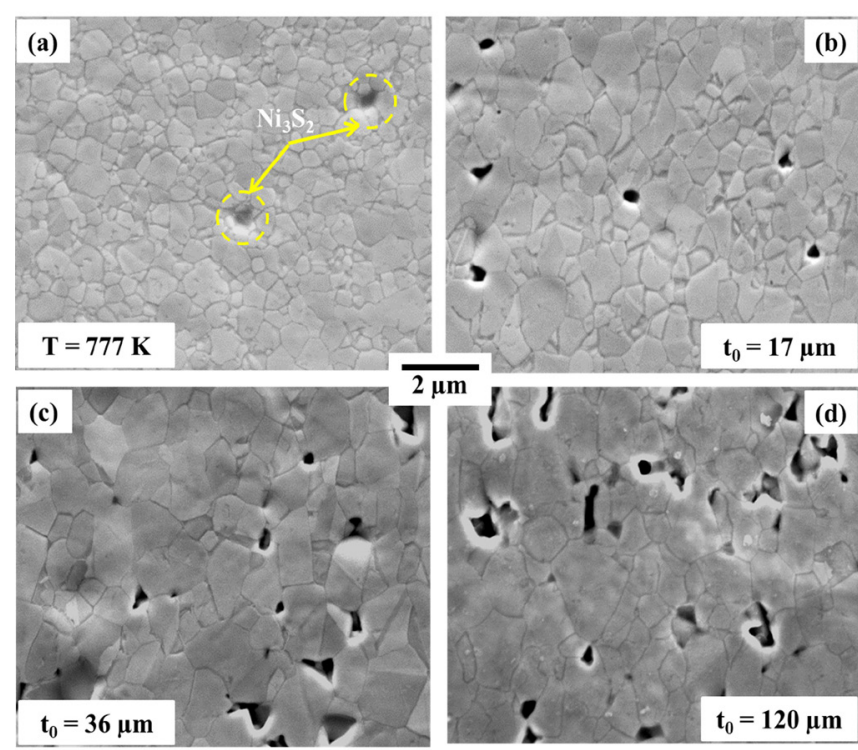

Fig. 4. Secondary electron micrographs of nano-Ni (a) heated to test temperature of $777 \mathrm{~K}$, and the tensile specimens with an initial thickness of (b) $17 \mu \mathrm{m}$, (c) $36 \mu \mathrm{m}$ and (d) $120 \mu \mathrm{m}$ deformed at $777 \mathrm{~K}$ and $3 \times 10^{-1} \mathrm{~s}^{-1}$.

granular type failure. The SEM examination reveals the presence of oxide layer cracks on surfaces of the superplastically deformed specimens (Fig. 5b-d). The thickness of oxide layer was $\sim 1-5 \mu \mathrm{m}$. It suggests that oxide layer can influence the deformation behavior of thin specimens at elevated temperatures.

\section{Discussion}

Tensile data at $777 \mathrm{~K}$ of nano-Ni with different gauge lengths and thicknesses indicated significant specimen size effect on superplastic behavior. The elongation to failure increased with decreasing the gauge length and increasing the specimen thickness. The nominal true stress increased with decreasing specimen gauge length and thickness. The flow behavior changed from softening to hardening with reducing specimen dimensions.

Dalla Torre et al. [14] reported an increased strength and ductility in nano-Ni with grain size of $\sim 16 \mathrm{~nm}$ at room temperature by reducing the specimen gauge length from 20 $\mathrm{mm}$ to $3 \mathrm{~mm}$. They attributed this behavior to the reduced geometrical inhomogeneities due to the specimen cutting process in a specimen with small gauge length. Zhao et al. [15] studied the specimen thickness $(0.25-2 \mathrm{~mm})$ and gauge length $(1-10 \mathrm{~mm})$ effect on flow behavior of copper at room temperature. They observed an increased ductility with decreasing gauge length and increasing specimen thickness, and this was ascribed to the increased post-necking elongation. Miyazaki et al. [17] studied the effect of ratio of specimen thickness to average grain size $(t / d)$ on room temperature flow behavior of $\mathrm{Al}$ and $\mathrm{Cu}$ alloys. An increased flow stress with increasing specimen thickness $(0.045-1.84 \mathrm{~mm})$ was observed below a critical $t / d$ ratio; the critical $t / d$ ratio increased with decreasing the grain size. The critical $t / d$ ratio was found to be $\sim 10-20$. There are reports on specimen size effect on superplastic behavior of materials at elevated
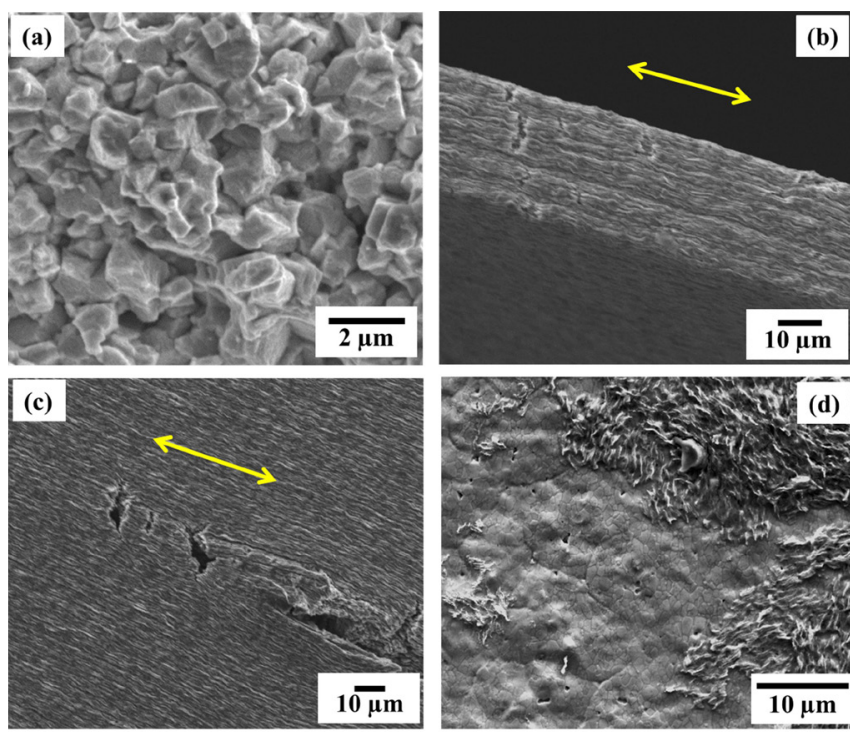

Fig. 5. Secondary electron micrographs of nano-Ni showing (a) fracture surface, and the oxide layer cracks presence (normal to the tensile axis as shown by arrows) on specimen along (b) thickness and (c) width before polishing, and (d) the partially electropolished surface of the tensile specimen deformed at $777 \mathrm{~K}$ and $3 \times 10^{-1} \mathrm{~s}^{-1}$.

temperatures [15-17]. All these studies showed an increased elongation to failure with decreasing gauge length and increasing specimen thickness. Based on experimental observations in a superplastic $\mathrm{Pb}-\mathrm{Sn}$ alloy, Morrison [19] proposed an empirical equation relating the elongation to failure $\left(e_{f}\right)$ with the strain rate sensitivity $(m)$ and specimen geometry (gauge diameter, $d_{0}$ and length, $L_{0}$ ):

$$
e_{f}=C m^{2}\left(\frac{d_{0}}{L_{0}}\right) \times 100
$$

where $\mathrm{C}$ is a material constant. It is important to note that the Morrison's experiments were on large cylindrical specimens (3-6 $\mathrm{mm}$ in diameter and $12-100 \mathrm{~mm}$ length). In contrast to room temperature observations, Astanin et al. [21] reported flow stress reduction with increasing the specimen thickness in $\mathrm{Al}$ alloy under superplastic conditions ( $\mathrm{T} \sim 723 \mathrm{~K}$ ).

The present specimen gauge length effect observations on elongation to failure are consistent with the early reports of enhanced ductility with decreasing the gauge length and it could be related to the decreased specimen inhomogeneities. It is important to note that the flow stresses are calculated on the assumption of uniform elongation along gauge length, so that the nominal true stress values may be different from actual flow stress values due to flow localization. The increased ductility with increasing thickness of specimen could be related to an increased grain boundary sliding contribution to total strain as $\mathrm{t} / \mathrm{d}$ ratio increases and less interference of surface oxide layer. It is important to note that at failure the $t / d$ ratio was in the range of 10-20 for the specimens with different thicknesses. The surface morphology of the nano-Ni sample tested at $777 \mathrm{~K}$ showed the presence of oxide layer of $\sim 1-5$ $\mu \mathrm{m}$ thick. Wang et al. [22] studied the oxidation behavior of nano-Ni with a grain size of $\sim 40 \mathrm{~nm}$ using thermogravimetry and reported strong oxidation of nano-Ni at temperatures 
$>500 \mathrm{~K}$. Chan et al. [23] also reported static and dynamic oxidation of nano-Ni in tension at temperatures $>673 \mathrm{~K}$. The fine grain size in nano-Ni can enhance the oxidation tendency even at low temperatures. These studies suggest that the oxide layer formation on nano-Ni tensile specimens is inevitable at test temperatures $>673 \mathrm{~K}$. The oxide layer formed on surface of the specimen can start influencing the properties when the ratio of specimen thickness to oxide layer and the $t / d$ ratio decrease. During high temperature deformation the brittle oxide layers can be broken and new surfaces can be oxidized again. The repetitive process of oxide layer formation and breakage can be reflected as serrations in flow curves.

\section{Conclusions}

1. Electrodeposited nanocrystalline $\mathrm{Ni}$ exhibited an increased maximum stress and elongation to failure with decreasing the specimen gauge length. This could be related to the reduced geometrical inhomogeneities and defects concentration in smaller specimens.

2. There was an increased stress but decreased ductility in nano-Ni with decreasing the specimen thickness. This can be ascribed to the decreased grain boundary sliding contribution to total strain as the ratio of thickness to grain size decreases and also significant interference of surface oxide layer in thin specimens.

3 Deformation-induced grain growth and an intergranular failure were observed in superplastically deformed nanocrystalline $\mathrm{Ni}$.

Acknowledgements. Author is grateful to Prof.A. H. Chokshi, Department of Materials Engineering, IISc, Bangalore for his valuable guidance and support. Author would like to thank Department of Science and Technology (DST), India for financial support and also the Institute Nano Initiative, IISc, Bangalore for the electron microscopy facility.

\section{References}

1. C. Suryanarayana, JOM. 54 (9), 24 (2002).

2. M. A. Meyers, A. Mishra, D. J. Benson, Prog. Mater. Sci. 51, 427 (2006).
3. L. Wang, J. Zhang, Y. Gao, Q. Xue, L. Hu, T. Xu, Scripta Mater. 55, 657 (2006).

4. R.Z. Valiev, R. K. Islamgaliev, I. V. Alexandrov, Prog. Mater. Sci. 45, 103 (2000).

5. E. V. Avtokratova, O. M. Mukhametdinova, O. Sh. Sitdikov, M.V. Markushev, SV.S.N. Murty, M.J. N. V. Prasad, B. P. Kashyap, Lett. Mater. 4, 41 (2014).

6. A.H. Chokshi, A.K. Mukherjee, T.G. Langdon, Mater. Sci. Eng. R10, 237 (1993).

7. M. Kawasaki, T. G. Langdon, J. Mater. Sci. 42, 1782 (2007)

8. M. Kawasaki, R. B. Figueiredo, T. G. Langdon, Lett. Mater. 4, 78 (2014).

9. S.X. McFadden, A.P. Zhilyaev, R.S. Mishra, A. K. Mukherjee, Mater. Lett. 45, 345 (2000).

10. M. J. N. V. Prasad, A.H. Chokshi, Scripta Mater. 63, 136 (2010).

11. M. J. N. V. Prasad, A.H. Chokshi, Acta Mater. 58, 5724 (2010).

12. M. J. N. V. Prasad, A.H. Chokshi, Acta Mater. 59, 4055 (2011).

13. K.C. Chan, C.L. Wang, K.F. Zhang, G. Pang, Scripta Mater. 51, 605 (2004).

14. F. Dalla Torre, H. Van Swygenhoven, M. Victoria, Acta Mater. 51, 5159 (2003).

15. Y.H. Zhao, Y.Z. Guo, Q. Wei, T.D. Topping, A. M. Dangelewicz, Y. T. Zhu, T. G. Langdon, E. J. Lavernia, Mater. Sci. and Eng. A525, 68 (2009).

16. Y.H. Zhao, Y.Z. Guo, Q. Wei, A. M. Dangelewicz, C. Xu, Y. T. Zhu, T. G. Langdon, Y.Z. Zhou, E. J. Lavernia, Scripta Mater. 59, 627 (2008).

17. S. Miyazaki, K. Shibata, H. Fujita, Acta Metall. 27, 855 (1979).

18. N. Warthi, P. Ghosh, A.H. Chokshi, Scripta Mater. 68, 225 (2013).

19. W. B. Morrison, Trans. Metall. Society AIME. 242, 2221 (1968).

20. M. M. I. Ahmed, T. G. Langdon, Metall. Trans. 8A, 1832 (1977).

21. V.V. Astanin, K.A. Padmanabhan, S.S. Bhattacharya, Mater. Sci. Tech. 12, 545 (1996).

22. L. Wang, Z. Tan, S. Meng, D. Liang, B. Liu, Thermochim. Acta. 386, 23 (2002).

23. K. C. Chan, C. L. Wang, K. F. Zhang, Mater. Sci. Tech. 23, 677 (2007). 